\title{
Comparative Analysis of Direct and Indirect 131I Measurement Methods from the Stack to Outdoor
}

\author{
G. Suhariyono* and Bunawas \\ Center for Radiation Safety Technology and Metrology, National Nuclear Energy Agency, \\ Jl. Lebak Bulus Raya, No. 49, Jakarta 12440, Indonesia
}

\section{ARTICLE INFO}

\section{Article history:}

Received 31 October 2016

Received in revised form 17 May 2017

Accepted 22 May 2017

\section{Keywords:}

Stack

Iodine-131

${ }^{131} \mathrm{I}$

Outdoor

Charcoal

Environment

In-situ

Dispersion

Direct

Indirect

\begin{abstract}
A B S T R A C T
The radioisotope production facility at PUSPIPTEK Serpong produces and processes ${ }^{131}$ I that can disperse to the settlements (community) and the environment around the Serpong Nuclear Area (SNA). ${ }^{131} \mathrm{I}$ is produced routinely for medical uses in hospitals and pharmacies, for both domestic uses and export. ${ }^{131} \mathrm{I}$ is a beta and gamma emitting radioactive material and can cause thyroid cancer. The problem was that there was so far no research and in-depth assessment of the aerial dispersion of ${ }^{131}$ I radioactivity emitted from the radioisotope production stack to the environment at actual conditions. The research was conducted through simultaneous measurement of ${ }^{131}$ I radioactivity in the stack of the ${ }^{131}$ I radioisotope production facility, Serpong, and outdoor in house courtyards around SNA in normal condition (no accident) based on the variations of the distance and wind direction. Direct measurements were carried out with a portable in-situ $\mathrm{NaI}(\mathrm{Tl})$ detector at outdoor, and with a $\mathrm{LaBr}_{3}$ detector in the stack. Indirect measurements were carried out by using charcoal filter and vacuum pump in the stack and outdoor. The direct measurement method has many advantages over the indirect measurement. The direct measurement method was found to be more accurate, less expensive, easier to operate, needing just one operator in its implementation, portable, and can be operated continuously and for long durations. The overall activity concentrations of ${ }^{131} \mathrm{I}$ on average obtained by either direct or indirect method were still below the upper limit of ${ }^{131} \mathrm{I}$ activity concentration in the air $\left(530 \mathrm{~Bq} / \mathrm{m}^{3}\right.$ ) stipulated by the Regulation of the Chairman of BAPETEN (Perka BAPETEN) No. 7/2013.
\end{abstract}

\section{INTRODUCTION}

The ${ }^{131}$ I radionuclide is the one of the most common radionuclides released from a nuclear accident [1-3]. ${ }^{137} \mathrm{Cs}$ is the second most released radionuclide, under ${ }^{131} \mathrm{I}$. Therefore, a ${ }^{131} \mathrm{I}$ release is to be anticipated in the event of a nuclear emergency. From the experiences from other countries, for example, it was found that the activity of the ${ }^{131} \mathrm{I}$ radionuclide is released from nuclear accidents at the Oak Ridge laboratory (Tennessee, USA) in 1944-1956 was a much as 0.30 to $1.55 \mathrm{PBq}$, while at Hanford (Washington State,

\footnotetext{
* Corresponding author.

E-mail address: g_suhariyono@batan.go.id

DOI: https://doi.org/10.17146/aij.2017.756
}

USA) from 1944 to 1972 it was $27.83 \mathrm{PBq}$, and in Nevada, USA, from 1952 to 1970 was as much as 5,550 PBq. Furthermore, the Three Mile Island accident in 1979 released as much as $555-777 \mathrm{GBq}$, the Chernobyl (Ukraine) accident in 1986 released $1,850 \mathrm{PBq}$, the Savannah River (South Carolina, USA) operation in 1955-1990 released as much as $2.22 \mathrm{PBq}$, and the Fukushima (Japan) accident in March 2011 released as much as $400 \mathrm{PBq}$ [1- 6].

Radioiodine $\left({ }^{131} \mathrm{I}\right)$ is one of the radioactive substances sufficiently significant to get attention, because it is volatile with a probability of $81.21 \%$ of its formation greater than the other radioiodine isotopes [1]. Based on EPA RadNet measurement, $81 \%$ of ambient ${ }^{131} \mathrm{I}$ was detected in the gas phase and $19 \%$ was detected in the particle phase [3]. 
The thyroid gland is the most critical human organs affected by ${ }^{131} I$ [ [7]. If the ${ }^{131} \mathrm{I}$ is located in the human body, then the ${ }^{131}$ I will enter the thyroid through the metabolism of the body carried by the blood [8]. The chemical properties of ${ }^{131} \mathrm{I}$ are similar with those of stable iodine, so ${ }^{131} \mathrm{I}$ can damage the thyroid gland and damage the health $[9,10] .{ }^{131} \mathrm{I}$ that is dispersed from the stack to the environment can also impact the economy of the society [11].

A radioisotope production facility is located in the Research Center for Science and Technology (PUSPIPTEK - Pusat Penelitian Ilmu Pengetahuan dan Teknologi in Indonesian) in Serpong, Indonesia. This facility produces several radioisotopes for both domestic and export purposes; one of those radioisotopes is ${ }^{131} \mathrm{I}$ that was routinely produced for medical purposes in hospitals and pharmacies. The experiment presented here ran from December 2013 to March 2014. This facility is located in the Serpong Nuclear Area (SNA) that is surrounded by dense residential population. Residents in the area of $5 \mathrm{~km}$ radius from PUSPIPTEK in 2012 are around 213,837 people [12,13]. This is a cause for concern for BATAN (National Nuclear Energy Agency) and BAPETEN (Nuclear Energy Regulatory Agency), as it necessitates research on the radionuclide releases in general, especially the release of Iodine-131 ( $\left.{ }^{131} \mathrm{I}\right)$ from the stack in the radiation facilities into the environment. Therefore, it is necessary to research and study the concentration of ${ }^{131} \mathrm{I}$ released from the stack to the settlements around the SNA based on the variation of the distance and direction of wind by using direct and indirect methods simultaneously. Direct measurements were performed outdoors and in the stack. Outdoors, the measurements used a portable $\mathrm{NaI}(\mathrm{Tl})$ detector in situ, while in the stack, $\mathrm{LaBr}_{3}$ detectors were used. Indirect measurements by using a charcoal filter and vacuum pump were also performed both in the stack and outdoor. The maximum acceptable activity concentration of ${ }^{131} \mathrm{I}$ in the air, also known as the quality standard value, is $530 \mathrm{~Bq} / \mathrm{m}^{3}$, as stipulated by the Regulation of the Chairman of BAPETEN (Perka BAPETEN in Indonesian) No. 7/2013 [14].

\section{EXPERIMENTAL METHODS}

\section{Description of study area}

The study was conducted in courtyards of seven houses (outdoor), Serpong Nuclear Area, and in the stack of the ${ }^{131} \mathrm{I}$ radioisotope production installation, BATAN, Serpong. The study was conducted in as many as seven houses with five wind directions for approximately 15 to 22 hours at the same time as the production and release of ${ }^{131} \mathrm{I}$ from the stack (Fig. 1). The research locations are:

1. North of the stack: $0.8 \mathrm{~km}$, Sengkol, Muncul Village, Banten.

2. North of the stack: $2.6 \mathrm{~km}$, BATAN Indah housing complex, Kademangan Village, Banten.

3. North of the stack: $4.2 \mathrm{~km}$, Jaletreng, Serpong Village, Banten.

4. East of the stack: $2.2 \mathrm{~km}$, Housing complex of Puri Serpong, Setu Village, Banten.

5. North East of the stack: $1.3 \mathrm{~km}$, Muncul, Setu Village, Banten.

6. South of the stack: $1.9 \mathrm{~km}$, Pabuaran Village, Bogor, West Java.

7. West of the stack: $3.2 \mathrm{~km}$, Housing complex of Griya Serpong Asri, Suradita Village, Banten.

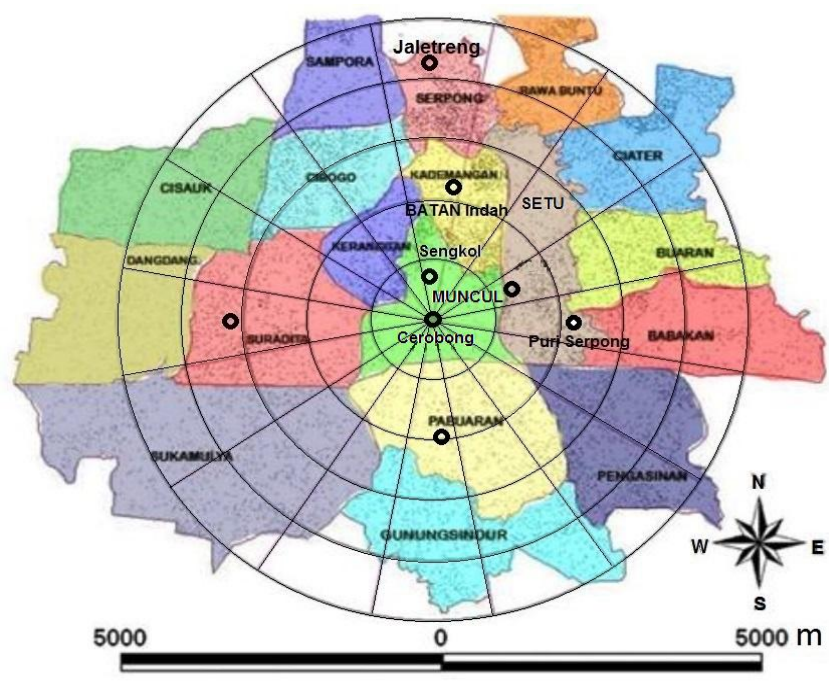

Fig. 1. Research location at Serpong Nuclear Area (SNA).

\section{Monitor calibration of ${ }^{131} \mathrm{I}$ radioactive gas}

The measurement of ${ }^{131} \mathrm{I}$ radioactive gas was conducted by using direct and indirect methods. The direct method was conducted by direct measurement of the ${ }^{131} \mathrm{I}$ air concentration from the stack with an $\mathrm{LaBr}_{3}$ (lanthanum (III) bromide) scintillation detector. The indirect method was performed by using activated charcoal filter (charcoal) $[15,16]$. The concentration of ${ }^{131} \mathrm{I}$ adsorbed in the charcoal was detected by scintillation detector of $\mathrm{NaI}(\mathrm{Tl})$ in a research laboratory.

The calibration of $\mathrm{LaBr}_{3}$ scintillation detector was conducted by counting three radiation standard sources, i.e., Barium-133 $\left({ }^{133} \mathrm{Ba}\right)$, Cesium-137 $\left({ }^{137} \mathrm{Cs}\right)$, and Cobalt-60 $\left({ }^{60} \mathrm{Co}\right)$. Activity of ${ }^{133} \mathrm{Ba}$ on 
December 2, 2013 was $79.238 \mathrm{kBq}$. The activities of ${ }^{137} \mathrm{Cs}$ and ${ }^{60} \mathrm{Co}$ on April 1, 2000 was $116 \mathrm{kBq}$ and $213 \mathrm{kBq}$, respectively. The ${ }^{133} \mathrm{Ba}$ source with a half-life of 10.51 years has several different gamma energies, but the greatest absolute emission probability is the $62.05 \%$ associated with the $356.017 \mathrm{keV}$ emission. The ${ }^{137} \mathrm{Cs}$ nuclide, with a half-life of 30.07 years, has only one gamma energy, $661.60 \mathrm{keV}$, with an absolute emission probability of $85.21 \%$ with the energy of $661.660 \mathrm{keV}$. The source ${ }^{60} \mathrm{Co}$ with a half-year of 5.271 years has two gamma energies, 1173.237 and $1332.501 \mathrm{keV}$, each with an absolute emission probability of $99.97 \%$ and $99.99 \%$, respectively.

The calibration of $\mathrm{NaI}(\mathrm{Tl})$ scintillation detector that was to be used for counting charcoal in a stack was conducted by chopping radiation standard source of ${ }^{226} \mathrm{Ra}$ in the form of charcoal. The activity of ${ }^{226} \mathrm{Ra}$ on September 1, 1993, at 12.00, was $291.6 \mathrm{~Bq}$. The ${ }^{226} \mathrm{Ra}$ standard source has a half-life of 1600 years. The absolute emission probability of the $186.101-\mathrm{keV}$ gamma ray from ${ }^{226} \mathrm{Ra}$ decay is low $(3.5 \%)$. The gamma energy efficiency of ${ }^{226} \mathrm{Ra}$ that is used for calibration is obtained from two progenies of ${ }^{226} \mathrm{Ra}$, i.e., ${ }^{214} \mathrm{~Pb}$ and ${ }^{214} \mathrm{Bi}$. The gamma energies of ${ }^{214} \mathrm{~Pb}$ are 241.982 and $351.922 \mathrm{keV}$ with absolute emission probabilities of $7.5 \%$ and $35.8 \%$, respectively. The gamma energies of ${ }^{214} \mathrm{Bi}$ are 609.313 and $1238.11 \mathrm{keV}$ with absolute emission probabilities of $44.8 \%$ and $5.86 \%$, respectively.

The calibration of $\mathrm{LaBr}_{3}$ and $\mathrm{NaI}(\mathrm{Tl})$ detectors included efficiency calibration and energy calibration by using a source of radiation at a close distance to the detectors, but the radiation standard source was not attached to the detectors. Energy calibration was carried out by equating the display of the energy in the $\mathrm{X}$ axis of the measurement results on the radiation standard source to detector software with the actual energy of radiation standard sources. Efficiency calibration was conducted by converting the measurement results of the count rate of radiation standard sources in counts per second (cps) to the activity in becquerels (Bq). The counting efficiency of the $\mathrm{LaBr}_{3}$ detector was calculated using equation (1) [16]:

$$
\eta=\frac{\left(N_{t}-N_{B g}\right)}{(Y \cdot A) /(F . t)}=\frac{\left(N_{t}-N_{B g}\right) \cdot F \cdot t}{\text { Y.A }}
$$

In this equation, $\eta$ is the counting efficiency obtained from detector calibration $\left(\mathrm{cps} /\left(\mathrm{Bq} / \mathrm{m}^{3}\right)\right)$, $A$ is the activity of the standard radiation source (Bq), $N_{t}$ is the count rate of ${ }^{131}$ I given by the detector (cps), $N_{B g}$ is the background count rate, without ${ }^{131} \mathrm{I}$ (cps), $t$ is the counting duration (s), $F$ is the flow rate of vacuum pump air in the stack $\left(\mathrm{m}^{3} / \mathrm{s}\right)$, and $Y$ is the absolute emission probability of the particular radiation from the standard source $(\%)$.

The counting efficiency of $\mathrm{NaI}(\mathrm{Tl})$ detector was used to measure the activity of ${ }^{131} \mathrm{I}$ in charcoal that was subsequently calculated by equation (2) $[15]$ :

$$
\eta=\frac{\left(\mathrm{N}_{\mathrm{t}}-\mathrm{N}_{\mathrm{Bg}}\right)}{\mathrm{Y} \cdot \mathrm{A}}
$$

The unit of efficiency $(\eta)$ in equation (2) is $\mathrm{cps} / \mathrm{Bq}$. The flow rate does not appear in equation (2), because the flow rates that were used in the studies were different. For the direct method with $\mathrm{LaBr}_{3}$ detector in the stack, the flow rate of the vacuum pump was $20.651 \mathrm{pm}\left(3.44 \times 10^{-4} \mathrm{~m}^{3} / \mathrm{s}\right)$, whereas for in-situ measurements using $\mathrm{NaI}(\mathrm{Tl})$ detector in a survey car, it was $25 \mathrm{lpm}$ $\left(4.17 \times 10^{-4} \mathrm{~m}^{3} / \mathrm{s}\right)$. The counting efficiency of ${ }^{131} \mathrm{I}$ at $364.48 \mathrm{keV}$ gamma energy was obtained from the graph of counting efficiency on standard sources as a function of several energies of standard sources.

\section{Measurement method of ${ }^{131} \mid$ concentration in the stack}

As a method of radioactivity measurement in the stack of the radioisotope production facility, in this study, a portable air monitoring system that can be monitored directly and continuously was developed. The air monitoring system used a portable $\mathrm{LaBr}_{3}$ (lanthanum(III) bromide) scintillation detector; it did not need nitrogen gas and was connected to a laptop computer directly, so the count rate of the radioactive air that was released into the environment could be periodically monitored. The measurement of flow rate used a digital flow rate meter, so that the flow rate of the air being sampled can be continuously monitored on a laptop. The in-situ $\mathrm{LaBr}_{3}$ scintillation detector has a better resolution than the $\mathrm{NaI}(\mathrm{Tl})$ scintillation detector; therefore, radionuclide detection by using the $\mathrm{LaBr}_{3}$ detector was more accurate.

The air monitoring system in the stack is shown in Fig. 2. The ${ }^{131}$ I-containing air coming from the stack was drawn by the vacuum pump and was then conveyed to the Marinelli and was further conveyed to charcoal and to flowmeter. The ${ }^{131} \mathrm{I}$ contained in the air that was entering the Marinelli was detected the by using an $\mathrm{LaBr}_{3}$ detector. The activity of ${ }^{131} \mathrm{I}$ was measured once every ten minutes directly in the form of the count rate in the part of energy spectrum at around $364 \mathrm{keV}$.

The sampling and measurement of radioactive ${ }^{131}$ I gas in the stack was conducted by two methods, i.e., direct and indirect methods. The direct method 
was conducted through direct sampling and measurement of the air concentration of ${ }^{131} \mathrm{I}$ from the stack by using an $\mathrm{LaBr}_{3}$ scintillation detector every ten minutes continuously. The indirect method was conducted through ${ }^{131}{ }^{1}$ sampling by using activated charcoal filter every hour for 12 times. The measurement of the ${ }^{131} \mathrm{I}$ radionuclide in charcoal samples was conducted by using a gamma spectrometer system and an $\mathrm{NaI}(\mathrm{Tl})$ detector in situ for an hour. The ${ }^{131}$ I count rates obtained from both direct and indirect methods were converted into ${ }^{131} \mathrm{I}$ concentration $\left(\mathrm{Bq} / \mathrm{m}^{3}\right)$. The concentration of ${ }^{131} \mathrm{I}$ in charcoal (indirect method) was calculated by using equation (3) [15]:

$$
C=\frac{\left(N_{t}-N_{B g}\right)}{Y . t . \eta \cdot(t s . F)}
$$

In equation (3), $C$ is the concentration of ${ }^{131} \mathrm{I}$ $\left(\mathrm{Bq} / \mathrm{m}^{3}\right), \eta$ is the counting efficiency obtained from the $\mathrm{NaI}(\mathrm{Tl})$ detector calibration $(\mathrm{cps} / \mathrm{Bq}), N_{t}$ is the count of ${ }^{131} \mathrm{I}$ on charcoal (indirect method, in counts), $N_{B g}$ is the background counts without ${ }^{131} \mathrm{I}$ (counts), $t$ is the counting duration (s), $t s$ is the sampling time (s), $F$ is the flow rate of sampling $\left(\mathrm{m}^{3} / \mathrm{s}\right)$ and $Y$ is the absolute emission probability of the $364.48 \mathrm{keV}$ photon from decay of ${ }^{131} \mathrm{I}(81.21 \%)$.

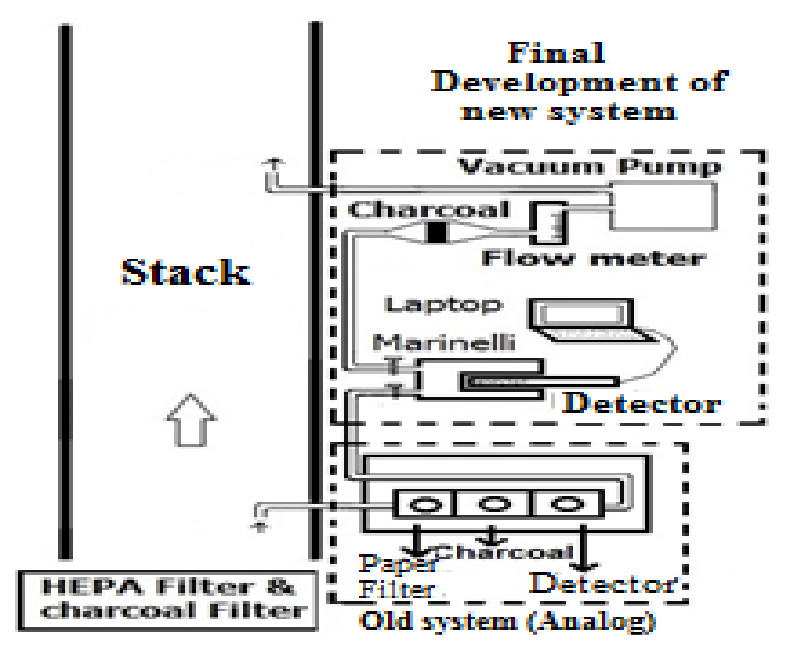

Fig. 2. Measurement system of ${ }^{131} \mathrm{I}$ in the stack.

The flow rate $(F)$ obtained from measurement sampling of the ${ }^{131} \mathrm{I}$ concentration in the stack was $20.65 \mathrm{lpm}\left(3.44 \times 10^{-4} \mathrm{~m}^{3} / \mathrm{s}\right)$. The calculation of the concentration of ${ }^{131} \mathrm{I}$ from direct method using the $\mathrm{LaBr}_{3}$ detector was performed using equation (4) [16]:

$$
C=\frac{\left(N_{t}-N_{B g}\right)}{Y . \eta}
$$

The differences between equation (3) and equation (4) are that in equation (4) the unit of efficiency $\eta$ in equation (4) is $\mathrm{cps} /\left(\mathrm{Bq} / \mathrm{m}^{3}\right)$, whereas $N_{t}$ is obtained from the ${ }^{131} \mathrm{I}$ counts of the $\mathrm{LaBr}_{3}$ detector. The activity rate of the removable air containing ${ }^{131} \mathrm{I}$ from the stack for 1 year $\left(C_{t}\right)$ is calculated with using the equation [17]:

$$
C_{t}=C \cdot V \cdot T(\mathrm{~Bq} / \text { year })
$$

$V$ is the average flow rate of airborne in the stack $\left(1.699 \times 10^{5} \mathrm{~m}^{3} / \mathrm{h}\right)$, while $T$ is the maximum duration of operation time per year (h/year). If the activity rate is calculated in the unit of $\mathrm{Bq} / \mathrm{h}$ from the equation (5), that activity rate is calculated without the variable of $T$ (h/year). Daily, the operating duration of ${ }^{131} \mathrm{I}$ radioisotope production was from 8 to 12 hours. The production of ${ }^{131} \mathrm{I}$ radioisotopes usually took place between 30 to 40 times a year. The variable $T$ is taken to be the maximum value of the operations of radioisotopes production, namely 480 hours/year. Based on the Decree of the Chairman of the Radiation Protection Commission of the SNA, No. 01/KNS/III/2011, the release limit of ${ }^{131} \mathrm{I}$ radionuclide into the atmosphere in the SNA is $3.19 \times 10^{8} \mathrm{~Bq} /$ week $\left(1.90 \times 10^{6} \mathrm{~Bq} / \mathrm{h}\right)$. The value of standard quality level of radioactivity in the air is $530 \mathrm{~Bq} / \mathrm{m}^{3}$ based on the Regulation of the Chairman of BAPETEN No. 7/2013 [14].

\section{Measurement method of outdoor ${ }^{131}$ I concentration}

The measurement of the outdoor ${ }^{131} \mathrm{I}$ concentration was conducted through observations at open locations away from buildings and trees. The measurement of ${ }^{131} \mathrm{I}$ in the air was conducted through two methods, i.e., direct measurement method and indirect method. The indirect measurement method of the ${ }^{131} \mathrm{I}$ concentration in the air was used by BATAN periodically, once every three months. Filter paper and charcoal were used as a means of ${ }^{131}$ I gas sampling in the indirect method. The sampling tool was placed $\pm 2.5 \mathrm{~m}$ above the ground by using isokinetic probe on the environment survey car overlooking to the stack as a source of air release (Fig. 3). The sampling tool of ${ }^{131}$ I was regulated by a vacuum pump at a flow rate of $25 \mathrm{lpm}$ and turned on for one hour. The filter that had been used for sampling for an hour was replaced by another charcoal filter. This operation continued until the production of ${ }^{131} \mathrm{I}$ in the stack finished. The filter papers and charcoal were then counted by using detector of $\mathrm{NaI}(\mathrm{Tl})$ in situ.

The direct measurement method of the ${ }^{131} \mathrm{I}$ concentration in the air is shown in Fig. 4. The direct measurement method of the ${ }^{131} \mathrm{I}$ content 
of outdoor was conducted above the environment survey car. The measurement was conducted directly by using in-situ portable $\mathrm{NaI}(\mathrm{Tl})$ detector attached to the top of the car. In the measurement of ${ }^{131} \mathrm{I}$ in the outdoor air, the detector was positioned to face upward. Protective $\mathrm{Pb}$ was installed in the vicinity of the detector, so that only ${ }^{131} \mathrm{I}$ radiation coming from above or from below would be detectable. This detector was connected to the laptop directly, so that the spectrum of ${ }^{131}$ I could be immediately detected on the $364 \mathrm{keV}$ energy. The concentration of ${ }^{131} \mathrm{I}$ in the air that was measured by the indirect method was calculated based on equation (3). If it was measured by the direct method, it would be calculated by equation (4).
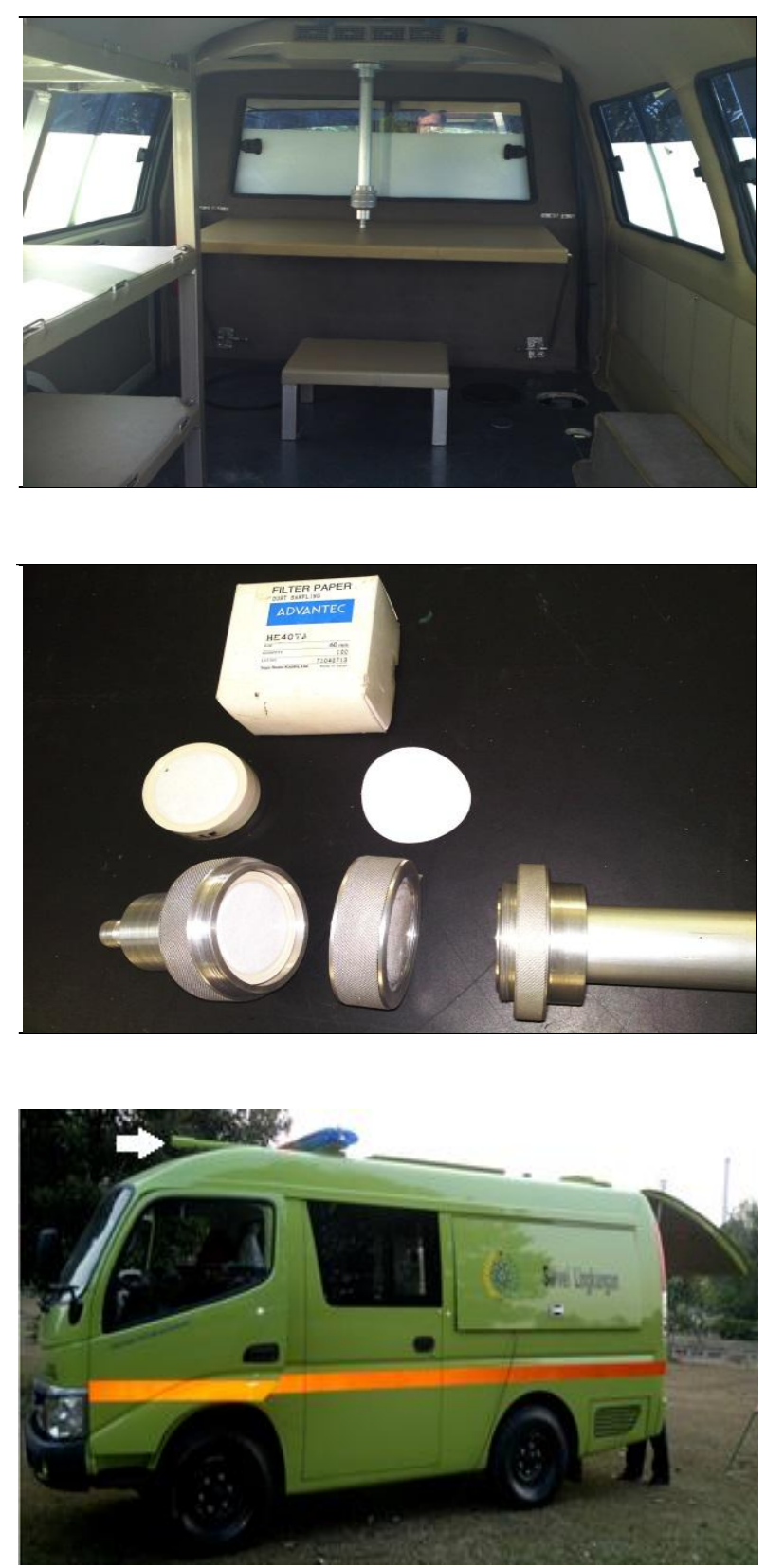

Fig. 3. Air sampling system with indirect method by using charcoal.

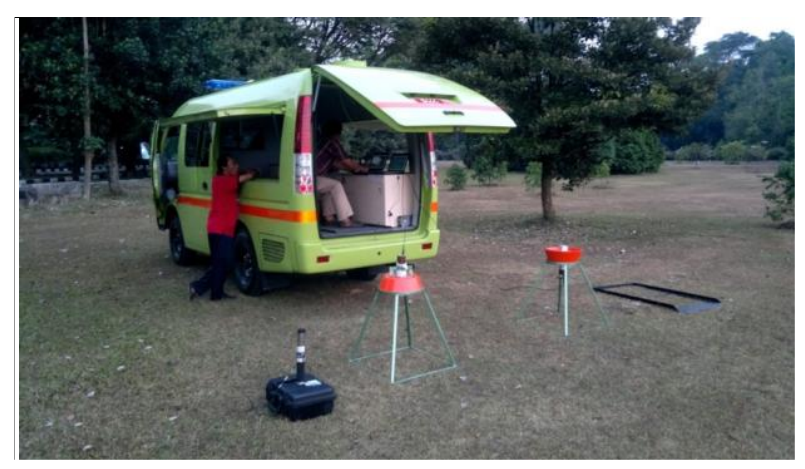

Fig. 4. Outdoor air measurement of ${ }^{131} \mathrm{I}$ by direct method.

\section{RESULTS AND DISCUSSION}

\section{Calibration of $\mathrm{LaBr}_{3}$ detector}

The $\mathrm{LaBr}_{3}$ scintillation detector was calibrated by counting three standard radiation sources, i.e., ${ }^{133} \mathrm{Ba},{ }^{137} \mathrm{Cs}$, and ${ }^{60} \mathrm{Co}$. The calibration results are shown in Table 1 and Fig. 5. The calculation of efficiency used equation (1). The flow rate of the air sampling from the vacuum pump in the stack was $20.65 \mathrm{lpm}\left(3.44 \times 10^{-4} \mathrm{~m}^{3} / \mathrm{s}\right)$. The calculation results of efficiency was graphed against the gamma energy $(\mathrm{keV})$. Efficiency of the detector $(y)$ at the energy of ${ }^{131} \mathrm{I}(x=364.48 \mathrm{keV})$ was obtained, from the calculation of the equation $y=5 \times 10^{-10} x^{2}-1 \times 10^{-06} x+$ $8 \times 10^{-4}$, to be $0.0004919 \mathrm{cps} /\left(\mathrm{Bq} / \mathrm{m}^{3}\right)$. This value of efficiency was then used to calculate the activity concentration $\left(\mathrm{Bq} / \mathrm{m}^{3}\right)$ on equation (4).

Table 1. The results of efficiency calculation by using $\mathrm{LaBr}_{3}$ detector

\begin{tabular}{ccccccccc}
\hline $\begin{array}{c}\text { Radiation Energy } \\
\text { source } \\
(\mathrm{keV})\end{array}$ & $\begin{array}{c}\text { Absolute } \\
\text { emission } \\
\text { probability } \\
(\%)\end{array}$ & $\begin{array}{c}T_{1 / 2} \\
(\text { Year })\end{array}$ & $\begin{array}{c}\text { Source } \\
\text { count } \\
(\mathrm{cps})\end{array}$ & $\begin{array}{c}\text { Back- } \\
\text { ground } \\
\text { count } \\
(\mathrm{cps})\end{array}$ & $\begin{array}{c}\text { Activity at } \\
14-3-2014\end{array}$ & $\begin{array}{c}\text { Counting } \\
\text { efficiency } \\
\left(\mathrm{cps} /\left(\mathrm{Bq} / \mathrm{m}^{3}\right)\right)\end{array}$ \\
\hline${ }^{133} \mathrm{Ba}$ & 356.02 & 62.05 & 10.51 & 127.86 & 0.33 & $77,791.56$ & 0.0005014 \\
\hline${ }^{137} \mathrm{Cs}$ & 661.66 & 85.21 & 30.07 & 114.41 & 41.63 & $84,102.99$ & 0.0003022 \\
\hline${ }^{60} \mathrm{Co}$ & $1,173.2$ & 99.97 & 5.27 & 30.14 & 0.83 & $34,019.18$ & 0.0001677 \\
\hline & $1,332.5$ & 99.99 & 5.27 & 29.96 & 0.99 & $34,019.18$ & 0.0001667 \\
\hline
\end{tabular}

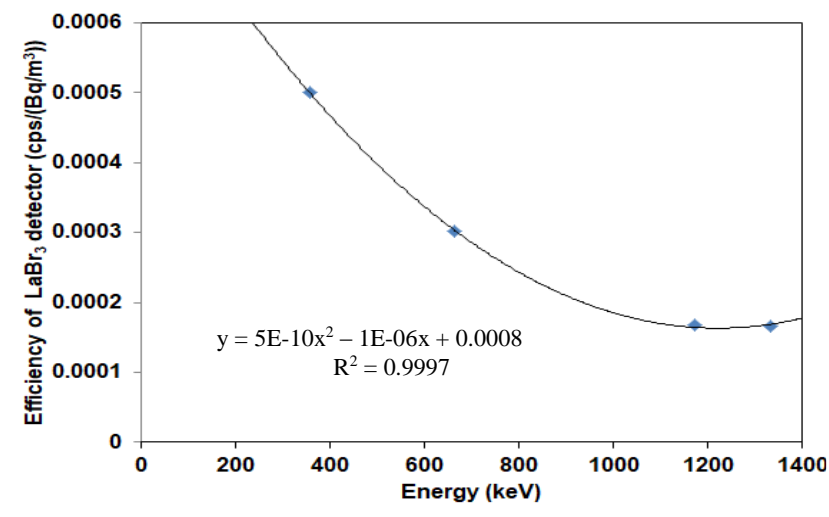

Fig. 5. $\mathrm{LaBr}_{3}$ detector counting efficiency as a function of radiation source energy. 


\section{Calibration of In-Situ Nal(TI) scintillation detector to measure ${ }^{131}$ I in charcoal}

The in-situ $\mathrm{NaI}(\mathrm{Tl})$ detector was calibrated by using ${ }^{226} \mathrm{Ra}$ standard source in charcoal. The results of the calibration of in-situ $\mathrm{NaI}(\mathrm{Tl})$ detector with ${ }^{131} \mathrm{I}$ samples in the charcoal are displayed on Table 2 and Fig. 6. The calculation of the detector efficiency of $\mathrm{NaI}$ (Tl) in-situ used equation (2). The calculation results of efficiency was then graphed against energy $(\mathrm{keV})$. The efficiency of the detector $(y)$ for the energy of ${ }^{131} \mathrm{I}(x=364.48 \mathrm{keV})$ was obtained as $0.035 \mathrm{cps} / \mathrm{Bq}$ from the equation $y=3 \times 10^{-10} x^{3}-4 \times 10^{-}$ ${ }^{7} x^{2}+2 \times 10^{-4} x+4 \times 10^{-4}$. The activity concentration $\left(\mathrm{Bq} / \mathrm{m}^{3}\right)$ of ${ }^{131} \mathrm{I}$ in the charcoal was then calculated by equation (3).

Table 2. The results of efficiency calculation of in-situ NaI (Tl) detector by using charcoal

\begin{tabular}{cccccccc}
\hline $\begin{array}{c}\text { Radiation } \\
\text { source }\end{array}$ & $\begin{array}{c}\text { Energy } \\
(\mathrm{keV})\end{array}$ & $\begin{array}{c}\text { Absolute } \\
\text { emission } \\
\text { probability } \\
(\%)\end{array}$ & $\begin{array}{c}\mathrm{T}_{1 / 2} \\
\text { Ra-226 } \\
(\text { tahun })\end{array}$ & $\begin{array}{c}\text { Source } \\
\text { count } \\
(\mathrm{cps})\end{array}$ & $\begin{array}{c}\text { Back- } \\
\text { ground } \\
\text { count } \\
(\mathrm{cps})\end{array}$ & $\begin{array}{c}\text { Activity } \\
\text { Ra-226 } \\
26-2014 \\
(\mathrm{~Bq})\end{array}$ & $\begin{array}{c}\text { Efficiency } \\
(\mathrm{cps} / \mathrm{Bq})\end{array}$ \\
\hline${ }^{214} \mathrm{~Pb}$ & 241,98 & 7,50 & 1.600 & 0,62 & 0,02 & 289,023 & 0.029 \\
\hline & 351,92 & 35,80 & 1.600 & 3,43 & 0,10 & 289,023 & 0.033 \\
\hline${ }^{214} \mathrm{Bi}$ & 609,31 & 44,80 & 1.600 & 5,10 & 0,13 & 289,023 & 0.039 \\
\hline & $1.238,11$ & 5,86 & 1.600 & 3,21 & 0,11 & 289,023 & 0.189 \\
\hline
\end{tabular}

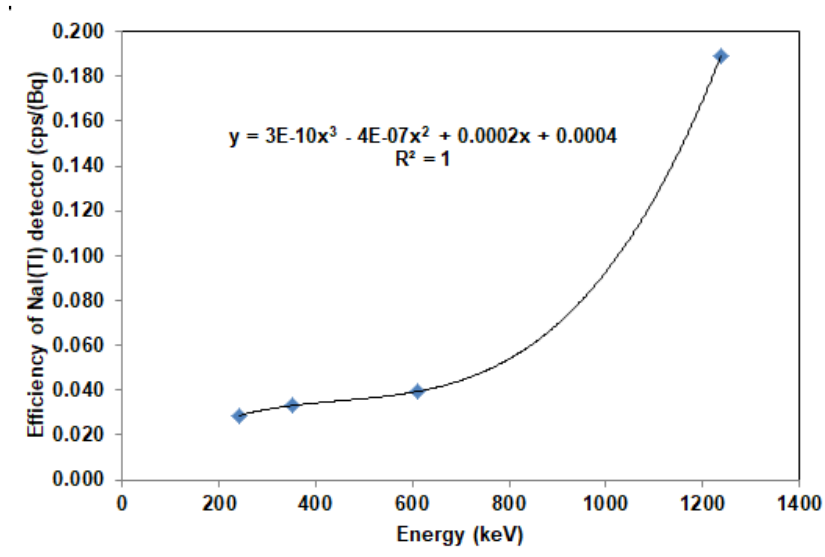

Fig. 6. Efficiency of in-situ $\mathrm{NaI}(\mathrm{Tl})$ detector on charcoal as a function of radiation source energy.

\section{Measurement of concentration of ${ }^{131}$ I activity in the stack}

Measurements of the ${ }^{131} \mathrm{I}$ activity concentration were carried out in the stack and outdoors near the Muncul junction together on December 27 and 28, 2013. The production process of ${ }^{131}$ I on those dates took place fom 13:30 to 05:00. Around 16:00 to $18: 00$ and 21:00 to $23: 00$ the process of the production of radioisotopes stopped because of broken instruments.
As an example, the measurements results of ${ }^{131}$ I activity concentration were the highest of indirect measurement systems on December 11 and 12, 2013, i.e., $470.35 \mathrm{~Bq} / \mathrm{m}^{3}$ between 19:00 and 20:00 (Fig. 7). The ${ }^{131}$ I activity concentration was high between 19:00 and 20:00, since at that time occurred a phase change from solution to gas, namely the separation between the ${ }^{99} \mathrm{Mo}$ solution and the ${ }^{131}$ I gas. There was ${ }^{131}$ I gas released through the sidelines of the rubber connector into the stack during the gas phase, so the ${ }^{131}$ I activity concentration rose for some time between 19:00 and 20:00. This case was in contrast with the results of direct measurements by using the $\mathrm{LaBr}_{3}$ detectors (Fig. 8). Measurement of ${ }^{131} \mathrm{I}$ through direct method was performed once every 10 minutes, while the indirect measurement was once every hour. The highest ${ }^{131} \mathrm{I}$ activity concentration obtained from direct measurement, that was higher than the one from indirect measurement, was $498.35 \mathrm{~Bq} / \mathrm{m}^{3}$ at 19:37. The overall average activity concentration of ${ }^{131} \mathrm{I}$ obtained, either by direct methods $\left(321.16 \mathrm{~Bq} / \mathrm{m}^{3}\right)$ or indirectly $\left(103.03 \mathrm{~Bq} / \mathrm{m}^{3}\right)$, was still below the quality standard of ${ }^{131} \mathrm{I}$ radioactivity levels in the air of $530 \mathrm{~Bq} / \mathrm{m}^{3}$ based on the Regulation of the Chairman of BAPETEN No. 7/2013 [14].

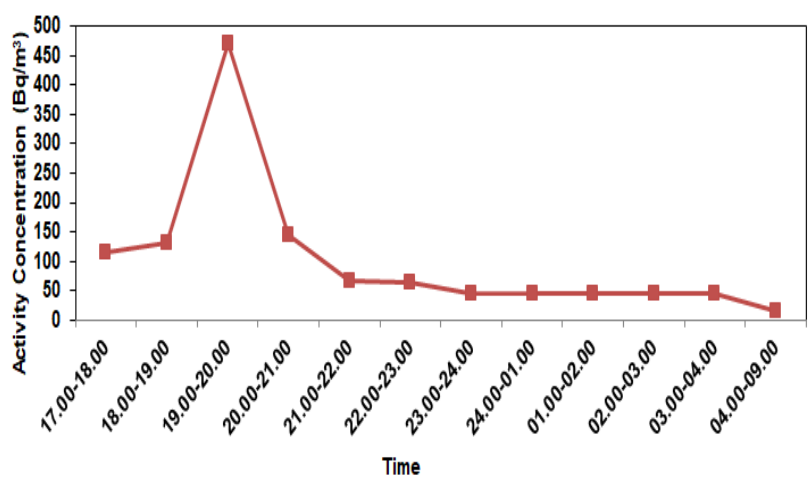

Fig. 7. Activity concentration of ${ }^{131} \mathrm{I}$ by using the indirect method on 11-12 December 2013 in the stack.

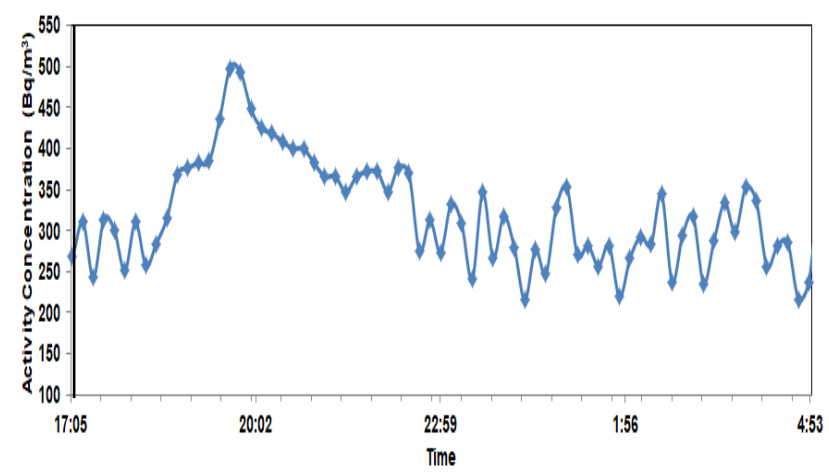

Fig. 8. Activity concentration of ${ }^{131} \mathrm{I}$ by using the direct method on 11-12 December 2013 in the stack. 
The measurement results of ${ }^{131}$ I activity concentration as a whole with both direct and indirect methods in the stack are shown in Table 3. The concentrations of the ${ }^{131} \mathrm{I}$ activity from the indirect measurement system on December 27 and 28 , 2013, were low compared to the ${ }^{131}$ I activity concentration in the stack on December 11 to 12 and December 18 to 19, 2013. Those low activities occurred because of broken instruments during the process of radioisotopes production, so the production of ${ }^{131} \mathrm{I}$ was not maximal. Direct measurements with $\mathrm{LaBr}_{3}$ detectors on December 27 and 28, 2013 were not conducted, because the laptop computer experienced an error.

The average ${ }^{131}$ I activity concentration in the stack obtained by indirect method was the highest on December 18 to 19,2013 , at. $217.24 \mathrm{~Bq} / \mathrm{m}^{3}$. With direct method, the highest average ${ }^{131}$ I activity concentration obtained in the stack was $374.67 \mathrm{~Bq} / \mathrm{m}^{3}$, also occurring on December 18 to 19, 2013. Both values were obtained from measurements performed in the BATAN Indah housing complex. The overall average activity concentration of ${ }^{131} \mathrm{I}$ obtained by either by direct or indirect method was still below the quality standard ${ }^{131} \mathrm{I}$ radioactivity levels in the air, i.e., $530 \mathrm{~Bq} / \mathrm{m}^{3}$ based on the Regulation of the Chairman of BAPETEN No. 7/2013 [14].

\section{Outdoor activity concentration of ${ }^{131}$ I}

The outdoor ${ }^{131} \mathrm{I}$ activity concentration, measured in the Puri Serpong housing complex on December 11 and 12, 2013, by using indirect and direct methods are shown on Fig. 9 and Fig. 10, respectively. The highest outdoor activity concentrations of ${ }^{131} \mathrm{I}$ measured by the indirect method and by direct method were almost the same, i.e., $30.14 \mathrm{~Bq} / \mathrm{m}^{3}$ at $19: 45$ to $20: 45$ and $30.05 \mathrm{~Bq} / \mathrm{m}^{3}$ at 19:36 to 20:36, respectively. Most of the total concentration, as much as $56 \%$, was derived from organic iodine concentration in the form of methyl iodide $\left(\mathrm{CH}_{3} \mathrm{I}\right)$, while $25 \%$ is in the form of $\mathrm{HOI}$ and $19 \%$ in $\mathrm{I}_{2}$. The time of occurrence of the highest ${ }^{131} \mathrm{I}$ activity concentration obtained by using the indirect method, namely from 19:45 to 20:45, coincided with the time of the highest activity concentration of ${ }^{131} \mathrm{I}$ by found using direct measurement methods on 19:36 to 20:36. The decline in the activity concentration of ${ }^{131} \mathrm{I}$ occurred at the same time for both methods, on $22: 36$ to $23: 36$ by direct method and on $22: 10$ to $23: 10$ by indirect method. This decrease was due to the high wind speed on those hours, at approximately $3.1 \mathrm{~m} / \mathrm{s}$.

The measurement results of outdoor ${ }^{131} \mathrm{I}$ concentration as a whole in the settlement areas around SNA by using the direct and indirect methods respectively are shown on Table 4 . The highest average outdoor concentration of ${ }^{131} \mathrm{I}$ at seven research sites occurred in the BATAN Indah housing complex, both by using direct $\left(29.81 \mathrm{~Bq} / \mathrm{m}^{3}\right)$ and indirect $\left(30.84 \mathrm{~Bq} / \mathrm{m}^{3}\right)$ methods. The measurements of the concentration of ${ }^{131} \mathrm{I}$ in BATAN Indah was conducted on different times depending on whether direct or indirect methods were used, with the indirect measurement performed from 11:30 to $01: 40$, and the direct measurement from 13:34 to 08:49. The magnitudes of the results were likewise different. The obtained highest average concentrations of ${ }^{131} \mathrm{I}$ in BATAN Indah were different on timing and magnitude, depending on the measurement method used, with the direct method result attaining the value until 01:40 and the direct method until 08:49. The concentration of ${ }^{131} I$ from 21:20 to $22: 25$ obtained by using direct measurement method was $55.15 \mathrm{~Bq} / \mathrm{m}^{3}$, almost equal to the highest total concentration of the ${ }^{131} \mathrm{I}$ activity $\left(54.34 \mathrm{~Bq} / \mathrm{m}^{3}\right)$ from the indirect method at the same time. Of the seven measurement sites, BATAN Indah exhibited the highest concentration of ${ }^{131} \mathrm{I}$, because on December 18 and 19, 2013, for the largest proportion of the time (37 \%) the wind direction was toward between the northwest and the northeast. Between September 2012 and August 2013, most of the time, the wind direction was toward between the northwest and the north at speeds between 2.1 to $5.7 \mathrm{~m} / \mathrm{s}$. Thus, on average, the dispersion of ${ }^{131} \mathrm{I}$ from the stack headed into settlements located north of the stack.

Table 3. The results of ${ }^{131} \mathrm{I}$ concentration measurements in the stack

\begin{tabular}{|c|c|c|c|c|c|c|c|c|}
\hline \multirow{3}{*}{ No. } & \multirow{3}{*}{\begin{tabular}{|c|} 
Location \\
Direction- \\
distance of stack
\end{tabular}} & \multirow{3}{*}{\begin{tabular}{|c|} 
Date \\
I-131 \\
production time \\
\end{tabular}} & \multicolumn{6}{|c|}{ Concentration $\left(\mathrm{Bq} / \mathrm{m}^{3}\right)$ and Time in the Stack } \\
\hline & & & \multicolumn{3}{|c|}{ Indirect Method } & \multicolumn{3}{|c|}{ Direct Method } \\
\hline & & & Minimum & Maximum & Average & Minimum & Maximum & Average \\
\hline \multirow{2}{*}{1} & Puri Serpong & 11-12 Des 2013 & 15.31 & 470.35 & 103.03 & 214.97 & 498.39 & 321.16 \\
\hline & $\mathrm{E}, 2.2 \mathrm{~km}$ & $17.00-05.00$ & $04.00-09.00$ & $19.00-20.00$ & $17.00-09.00$ & 24.20 & 19.37 & $17.00-05.00$ \\
\hline \multirow{2}{*}{2} & BATAN Indah & 18-19 Des 2013 & 55.67 & 771.96 & 217.24 & 160.12 & 800.84 & 374.67 \\
\hline & $\mathrm{N}, 2.6 \mathrm{~km}$ & $11.30-21.40$ & $21.30-09.40$ & $12.30-13.30$ & $\mid 10.30-09.40$ & 11.30 & 12.59 & $11.30-21.40$ \\
\hline \multirow[b]{2}{*}{3} & Muncul & 27-28 Des 2013 & 3.70 & 40.68 & 19.31 & - & - & - \\
\hline & $\mathrm{NE}, 1.3 \mathrm{~km}$ & $13.30-05.00$ & $10.00-13.30$ & $18.15-19.15$ & $10.00-04.40$ & - & - & - \\
\hline \multirow{2}{*}{4} & Sengkol & 22-23 Jan 2014 & 5.83 & 1163.92 & 152.14 & 51.30 & 1113.75 & 192.29 \\
\hline & $\mathrm{N}, 0.8 \mathrm{~km}$ & $14.00-01.30$ & $24.00-01.00$ & $14.00-15.00$ & $\mid 13.00-10.00$ & 1.33 & 14.37 & $14.00-01.33$ \\
\hline \multirow{2}{*}{5} & Pabuaran & 5-6 Feb 2014 & 14.73 & 246.24 & 86.51 & 100.46 & 247.82 & 155.29 \\
\hline & $\mathrm{S}, 1.9 \mathrm{~km}$ & $12.30-21.30$ & $13.30-14.30$ & $15.30-16.30$ & $\mid 11.30-09.40$ & 21.33 & 15.50 & $12.28-21.35$ \\
\hline \multirow{2}{*}{6} & Suradita & $19-20 \mathrm{Feb} 2014$ & 3.55 & 230.52 & 107.73 & 37.88 & 228.10 & 132.38 \\
\hline & $\mathrm{W}, 3.2 \mathrm{~km}$ & $11.00-21.00$ & $10.00-11.00$ & $14.00-15.00$ & $\mid$\begin{tabular}{|c|}
$\mid 11.00-10.00$ \\
\end{tabular} & 20.08 & 14.34 & $11.02-20.08$ \\
\hline \multirow{2}{*}{7} & Jaletreng & 13-14 Mar 2014 & 0 & 323.84 & 95.69 & 67.26 & 330.13 & 162.46 \\
\hline & $\mathrm{N}, 4.2 \mathrm{~km}$ & $11.00-21.00$ & $09.00-11.00$ & $12.00-13.00$ & $11.00-10.00$ & 20.23 & 12.29 & $11.09-20.23$ \\
\hline
\end{tabular}




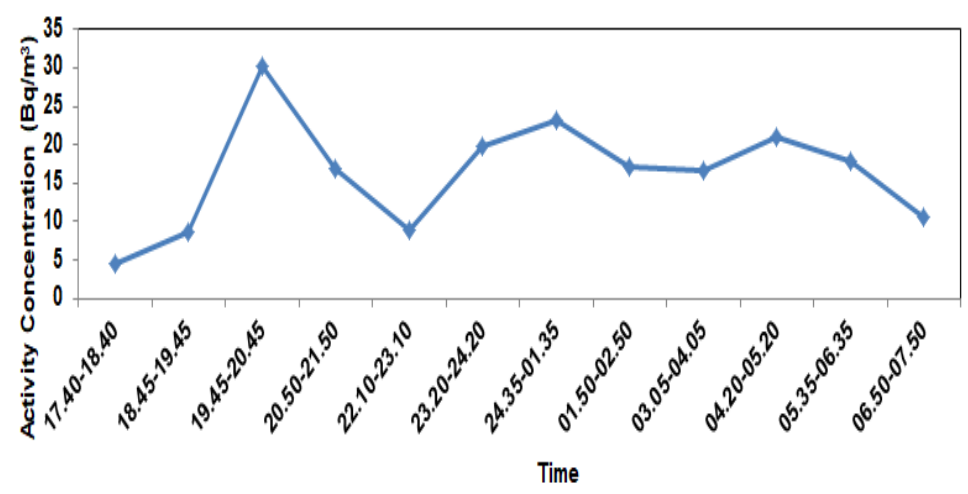

Fig. 9. ${ }^{131}$ I activity concentration in the outdoor ofth e Puri Serpong housing complex by using indirect method.

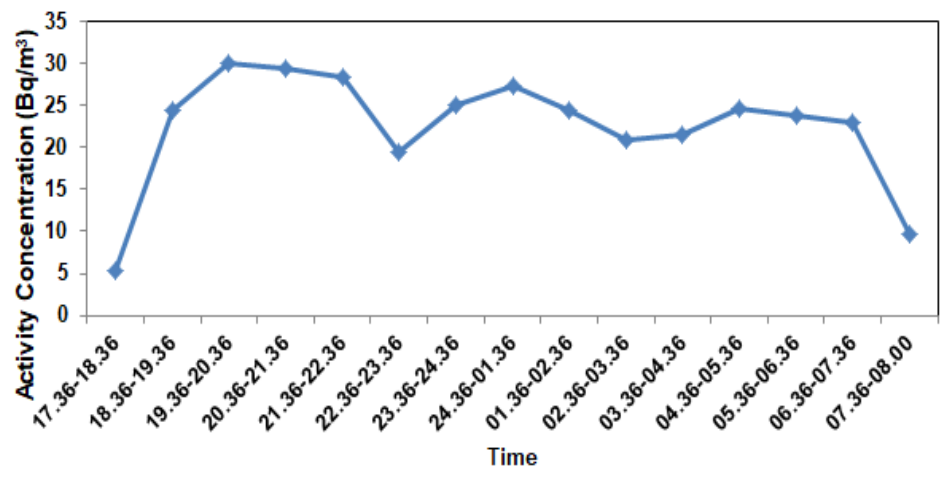

Fig. 10. ${ }^{131}$ I activity concentration in the outdoor of the Puri Serpong housing complex by using direct method.

Table 4. The results of outdoor ${ }^{131}$ I concentration measurements in the settlement areas around the SNA

\begin{tabular}{|c|c|c|c|c|c|c|c|c|}
\hline \multirow{3}{*}{ No. } & \multirow{3}{*}{$\begin{array}{c}\text { Location } \\
\text { Direction- } \\
\text { distance of stack }\end{array}$} & \multirow{3}{*}{\begin{tabular}{|c|} 
Date \\
I-131 \\
production time \\
\end{tabular}} & \multicolumn{6}{|c|}{ Concentration $\left(\mathrm{Bq} / \mathrm{m}^{3}\right)$ and Time at Outdoor } \\
\hline & & & \multicolumn{3}{|c|}{ Indirect Method } & \multicolumn{3}{|c|}{ Direct Method } \\
\hline & & & Minimum & Maximum & Average & Minimum & Maximum & Average \\
\hline \multirow{2}{*}{1} & Puri Serpong & 11-12 Des 2013 & 4.60 & 30.14 & 16.29 & 5.25 & 30.05 & 22.51 \\
\hline & $E, 2.2 \mathrm{~km}$ & $17.00-05.00$ & $17.40-18.40$ & $19.45-20.45$ & $17.40-07.50$ & $17.36-18.36$ & $19.36-20.36$ & $17.36-08.00$ \\
\hline \multirow[t]{2}{*}{2} & BATA & $18-19 \mathrm{D}$ & & & & 2.04 & & \\
\hline & & 11. & $1.30-12.30$ & 2.25 & $1.30-01.40$ & $13.34-14.34$ & 4.34 & 8.49 \\
\hline \multirow{2}{*}{3} & Muncul & $27-28$ & & 4 & 19.31 & 9.04 & 7 & 0 \\
\hline & $\mathrm{NE}, 1$ & 13. & 30 & $.45-22$. & $3.30-06.4$ & $39-15.39$ & $.39-22.39$ & $4.39-09.20$ \\
\hline \multirow{2}{*}{4} & Sengkol & 22-23 Jan 2014 & 9.37 & 30.39 & 21.42 & 0 & 32.66 & 15.39 \\
\hline & $\mathrm{N}, 0.8 \mathrm{~km}$ & $14.00-01.30$ & \begin{tabular}{|l|}
$14.10-15.10$ \\
\end{tabular} & $18.25-19.25$ & $14.10-07.50$ & $11.24-14.24$ & $18.24-19.24$ & 11.24-08.24 \\
\hline \multirow{2}{*}{5} & Pabuaran & 5-6 Feb 2014 & 10.81 & 32.33 & 20.67 & 0 & 32.48 & 11.96 \\
\hline & & & $30-08.30$ & 17.45 & $5.15-08.30$ & $11.53-13.53$ & $6.12-17.12$ & $11.53-10.12$ \\
\hline & . & 19-20 Feb 2014 & 0 & 27.95 & 12.94 & 0 & 4824 & 13.05 \\
\hline & & $11.00-$ & $4.05-16.30$ & $23.35-24.3$ & $14.05-09.00$ & $10.46-17.06$ & $23.06-24.06$ & $10.46-09.38$ \\
\hline & & $13-14$ & 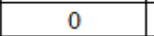 & & 17.01 & 0 & 55.78 & 13.17 \\
\hline & $\mathrm{N}, 4.2 \mathrm{~km}$ & $11.00-21.00$ & $15.10-16.10$ & $02.00-03.20$ & $15.10-09.00$ & $10.03-16.03$ & $01.03-02.03$ & $10.03-09.03$ \\
\hline
\end{tabular}

The concentrations of ${ }^{131} \mathrm{I}$ from the stack formed a parabolic curve to the north of the stack. This parabolic curve started to rise over the Sengkol settlement $(0.8 \mathrm{~km}$ of the stack), reached the highest value in BATAN Indah ( $2.6 \mathrm{~km}$ of the stack) and decreases into Jaletreng ( $4.2 \mathrm{~km}$ of the stack). The overall activity concentrations of ${ }^{131} \mathrm{I}$ of all the seven research sites by using direct or indirect methods were still below the quality standard of ${ }^{131} \mathrm{I}$ radioactivity levels in the air, i.e., $530 \mathrm{~Bq} / \mathrm{m}^{3}$ based on the Regulation of the Chairman of BAPETEN No. 7/2013 [14]. The outdoor concentrations of ${ }^{131}$ I measured at the seven housing locations were found not to give a significant risk to public health.

The comparison of direct (digital) and indirect (charcoal) measurement results are shown on Table 5. The comparison proves that the direct measurement method to be better than the indirect measurement method. The measurement system of radioactive releases in the stack of nuclear facilities by using direct methods can be used to replace the old indirect system of radioactive measurement (charcoal), because the direct system of measurement is more accurate, cheaper 
economically, easier to operate, requiring just one operator in its implementation, portable, and can be operated continuously for long periods of time.

Table 5. Comparison of direct and indirect measurements methods

\begin{tabular}{|c|c|c|c|}
\hline No. & Comparison of & $\begin{array}{l}\text { Direct method } \\
\quad \text { (digital) }\end{array}$ & $\begin{array}{l}\text { Indirect method } \\
\quad(\text { analog })\end{array}$ \\
\hline 1. & $\begin{array}{l}\text { Measurement } \\
\text { results }\end{array}$ & $\begin{array}{l}\text { The measurement } \\
\text { results can be } \\
\text { known directly in } \\
\text { the field or in the } \\
\text { stack. }\end{array}$ & $\begin{array}{l}\text { The results cannot be } \\
\text { immediately be known; } \\
\text { the charcoal is counted } \\
\text { first in the laboratory with } \\
\text { gamma spectrometry. }\end{array}$ \\
\hline 2. & Economy & $\begin{array}{l}\text { The cost is lower } \\
\text { (no filter), air is } \\
\text { detected by detector } \\
\text { via Marinelli with a } \\
\text { vacuum pump. }\end{array}$ & $\begin{array}{l}\text { The use of a charcoal, } \\
\text { filter paper and silver } \\
\text { screen are expensive. } \\
\text { The charcoal cost is } \\
\text { Rp. } 35,000 \text {, paper filter } \\
\text { Rp. } 250,000 / \text { box, silver } \\
\text { screen Rp. } 300,000 / \text { box, } \\
\text { plus the cost of shipping } \\
\text { import. }\end{array}$ \\
\hline 3. & Chemistry & $\begin{array}{l}\text { Compounds of }{ }^{131} \mathrm{I} \\
\text { with other elements } \\
\text { can not be detected. }\end{array}$ & $\begin{array}{l}\text { Compounds of }{ }^{131} \mathrm{I} \text { with } \\
\text { other elements }\left(\mathrm{CH}_{3} \mathrm{I}, \mathrm{I}_{2} \text {, }\right. \\
\text { and HOI) can be detected } \\
{[16,18] \text {. }}\end{array}$ \\
\hline 4. & $\begin{array}{l}\text { Operability for } \\
\text { long durations }\end{array}$ & $\begin{array}{l}\text { Radionuclide } \\
\text { detection can be } \\
\text { adjusted } \\
\text { periodically } \\
\text { (continuously) and } \\
\text { automatically. } \\
\end{array}$ & $\begin{array}{l}\text { Radionuclide detection } \\
\text { cannot be adjusted } \\
\text { periodically and not } \\
\text { automatically. }\end{array}$ \\
\hline 5. & Accuracy & $\begin{array}{l}\text { The measurement } \\
\text { results are more } \\
\text { accurate, } \\
\text { independent on the } \\
\text { pump flow rate of } \\
\text { air, air humidity, } \\
\text { and air temperature; } \\
\text { the energy spectrum } \\
\text { is viewable. }\end{array}$ & $\begin{array}{l}\text { The measurement results } \\
\text { are less accurate, } \\
\text { dependent on the flow } \\
\text { rate of air pumps, air } \\
\text { humidity, and air } \\
\text { temperature [19]. }\end{array}$ \\
\hline 6. & $\begin{array}{l}\text { Ease of } \\
\text { operation }\end{array}$ & $\begin{array}{l}\text { Easier to operate } \\
\text { and needing only } \\
\text { one operator. }\end{array}$ & $\begin{array}{l}\text { More hassle to operate } \\
\text { and needing more than } \\
\text { one operator. }\end{array}$ \\
\hline 7. & $\begin{array}{l}\text { Tool } \\
\text { portability }\end{array}$ & Portable & Not portable. \\
\hline
\end{tabular}

\section{CONCLUSION}

The direct measurement method has many advantages over the indirect measurement method. The direct measurement method is more accurate, less expensive, easier to operate, requiring just one operator in its implementation, portable, and can be operated continuously for long durations. The average ${ }^{131}$ I activity concentrations at any of the seven research sites surrounding the SNA, whether obtianed by using direct or indirect methods, in the stack or outdoor, was still below the quality standard of ${ }^{131} \mathrm{I}$ radioactivity levels in the air, i.e., $530 \mathrm{~Bq} / \mathrm{m}^{3}$ based on the Regulation of the Chairman BAPETEN No. 7/2013. The dispersion of ${ }^{131}$ I from the stack, on average, headed into settlements which were located north of the stack. The ${ }^{131} \mathrm{I}$ concentration formed a parabolic curve to the north of the stack, starting to rise from the Sengkol settlement $(0.8 \mathrm{~km}$ of stack), highest in BATAN Indah $(2.6 \mathrm{~km}$ of stack), and then declining to Jaletreng ( $4.2 \mathrm{~km}$ of stack).

\section{ACKNOWLEDGMENT}

The author would like to express their gratitude to Dr. Ir. Yudi Utomo Imardjoko (the Head of the Radioisotope Production Facility in Serpong, Indonesia), Dr. Ing. Kusnanto, and Abdurrahman Dzikri in Serpong who have allowed and assisted this research in the stack. They also thank the Minister of Research and Technology who had provided this research grants, as well as Prof. Haryoto Kusnoputranto (UI), Prof. Kardono (BPPT), and Dr. Syahrir (BAPETEN) who supported this research to be successful.

\section{REFERENCES}

1. Anonymous, Case studies in environmental medicine: Radiation exposure from Iodine131, Agency for Toxic Substances and Disease Registry (ATSDR), US Department of Health and Human Services (2008).

2. Anonymous, Sources, Effects and Risks of Ionizing Radiation: Levels and effects of radiation exposure due to the nuclear accident after the 2011 great East-Japan earthquake and tsunami, Scientific Annex A. United Nations Scientific Committee on the Effects of Atomic Radiation (UNSCEAR), Volume 1, Report to General Assembly, New York: United Nations publication (2014).

3. J.E.T. Hoeve and M.Z. Jacobson, J. Energy Environ. Sci. (2012). DOI: 10.1039/c2ee22019a.

4. M. Manolopoulou, E. Vagena, S. Stoulos et al., J. Environ. Radioac. 102 (2011) 796. DOI: 10.1016/j.jenvrad.2011. 04.010.

5. K. Tagami and S. Uchida, Chemosphere 84 (2011) 1282. DOI: 10.1016/j.chemosphere. 2011.05.050.

6. N. Momoshima, S. Sugihara, R. Ichikawa et al., J. Environ. Radioac. $\mathbf{x x x}$ (2011) 1. DOI: 10.1016/j.jenvrad.2011. 09.001.

7. E. Cardis and M. Hatch, Clinical Oncology 23 (2011) 251. DOI: 10.1016/j.clon.2011. 01.510.

8. V. Saenko, V. Ivanov, A. Tsyby et al., Clinical Oncology 23 (2011) 234. DOI: 10.1016/j. clon.2011.01.502. 
9. A. Baker, Air-sea exchange of Iodine, School of Environmental Sciences, University of East Anglia, Norwich, UK. http://www.uea.ac.uk/ e780/ airseaiod.htm. Retrieved in May (2011).

10. J.V. Carolan, C.E. Hughes, E.L. Hoffmann, J. Environ. Radioac. 102 (2011) 953. DOI:10.1016/j.jenvrad.2009.10.002.

11. H. Lehmann and J. Wadsworth, J. Health Economics 30 (2011) 843. DOI: 10.1016/j.jhealeco.2011.07.011.

12. Anonymous, Updates of Regional Serpong Nuclear Regions, Central Bureau of Statistics (BPS) of Tangerang Regency and Center for Radioactive Waste Technology-BATAN, National Nuclear Energy Agency (BATAN) (2012). (in Indonesian)

13. Untara, A.Yuniarto, Syahrir et al., Report on Monitoring the Radioactivity of the Serpong Nuclear Environment Area, Center for Radioactive Waste Technology, Serpong (2012). (in Indonesian)

14. Anonymous, Limit of Environmental Radioactivity, Nuclear Energy Regulatory Agency (BAPETEN), Number:
07/PERKA BAPETEN/2013, Jakarta (2013). (in Indonesian)

15. W.C. Hinds, Filtration, Aerosol Technology, John Wiley and Sons Inc., New York (1982).

16. C.G. Doll, C.M. Sorensen, T.W. Bowyer et al., J. Environ. Radioac. 130 (2014) 33.

17. Y. Sumarno, U. Hartoyo and A.M. Fahmi, ${ }^{131}$ I Concentration Analysis of Stack Air Release in Serba Guna Reactor of G.A. Siwabessy, Proceedings of the National Seminar IV of Human Resources and Nuclear Technology, STTN-BATAN, Yogyakarta (2008) 539. (in Indonesian)

18. F. Jimenez, R. Lopez, R. Pardo et al., Radiat. Meas. $\quad 46 \quad$ (2011) 104. DOI:10.1016/j.radmeas.2010.07.030.

19. G. Suhariyono, Bunawas and M. Wiyono, Adsorption Efficiency of ${ }^{131}$ I on Charcoal Filter to Temperature, Flow Rate, and Relative Humidity Function, Proceedings of the Scientific Seminar on Basic Research of Nuclear Science and Technology, PPNY-BATAN, Yogyakarta (1998) 463. (in Indonesian) 